\title{
Korean Red Ginseng Protects Oxidative Injury Caused by Lead Poisoning
}

\author{
Myoung Soo Park ${ }^{1 \#}$, Eun Jung Cho ${ }^{1 \#}$, Sang Ki Lee ${ }^{1,2}$, Eun Ji Lee ${ }^{1}$, Dae Sik Lee ${ }^{3}$, Kwon Ho Lee, \\ and Byeong Hwa Jeon ${ }^{{ }^{*}}$ \\ ${ }^{1}$ Department of Physiology, Research Institute for Medical Sciences, Chungnam National University School of Medicine, \\ Daejeon 301-131, Korea \\ ${ }^{2}$ Department of Sports Science, Chungnam National University, Daejeon 305-765, Korea \\ ${ }^{3}$ Department of Physical Therapy, Joongbu University, Kumsan 312-702, Korea
}

Lead $(\mathrm{Pb})$ is a metal that is generally considered to be toxic to the cardiovascular system. Pb-exposed animals display the evidence of increased oxidative stress and hypertension. The current study was designed to examine whether Korean red ginseng $(\mathrm{KRG})$ has protective effects against $\mathrm{Pb}$-induced hypertension and oxidative stress in $\mathrm{Pb}$-exposed rats. Male Sprague-Dawley rats were randomly assigned to $\mathrm{Pb}$ exposure or control groups. KRG was administered in drinking water at a concentration of $100 \mathrm{mg} / \mathrm{kg} /$ day; the control group received plain drinking water. Animals in the Pb-exposed groups were provided with drinking water containing $100 \mathrm{ppm} \mathrm{Pb}$ acetate for 12 weeks. Blood pressure, plasma glutathione, blood $\mathrm{Pb}$ concentration, and hematologic data, such as red blood cell quantity, were determined. $\mathrm{Pb}$ poisoning was assessed by measuring the blood $\mathrm{Pb}$ concentration. $\mathrm{Pb}$ exposure $(100 \mathrm{ppm})$ for 12 weeks resulted in a marked rise in systolic blood pressure and blood $\mathrm{Pb}$ concentration, as well as a significant reduction in plasma glutathione levels and red blood cell quantity. Other measurements, such as heart rate, body weight, and white blood cell quantity, were unchanged. Treatment with KRG significantly lowered blood pressure, raised plasma glutathione and increased red blood cell numbers in Pb-exposed animals; it also had no effect on heart rate, body weight, or white blood cell quantity. However, the elevated blood $\mathrm{Pb}$ concentration was not reduced by treatment with KRG $(100 \mathrm{mg} / \mathrm{kg})$. Taken together, these data indicate that treatment with $\mathrm{KRG}$ in $\mathrm{Pb}$-exposed animals can reduce oxidative stress and lower blood pressure, suggesting that KRG might be protective against $\mathrm{Pb}$-exposed hypertension and oxidative stress.

Keywords: Korean red ginseng, Lead, Blood pressure, Glutathione, Blood lead concentration

\section{INTRODUCTION}

Recent environmental pollution has contributed to an increase in the damage to human health caused by heavy metals. Among heavy metals, lead $(\mathrm{Pb})$ has long been recognized as one of the most harmful environmental pollutants. There are many ways in which humans are exposed to $\mathrm{Pb}$, through air, drinking water, food, and contaminated soil. Increased levels of $\mathrm{Pb}$ in the body interfere with a variety of physiological processes, resulting in toxicity to the cardiovascular and hematopoietic systems. In particular, chronic low-level $\mathrm{Pb}$ exposure has been shown to cause increased blood pressure in both humans and animals [1-3]. Recent re- (cc) This is an Open Access article distributed under the terms of the Creative Commons Attribution Non-Commercial License (http://creativecommons.org/licenses/by-nc/3.0/) which permits unrestricted non-commercial use, distribution, and reproduction in any medium, provided the original work is properly cited.
Received 3 Mar. 2010, Revised 14 Apr. 2010, Accepted 15 Apr. 2010

*Corresponding author

E-mail: bhjeon@cnu.ac.kr

Tel: +82-42-580-8214, Fax: +82-42-585-8440

\#These authors contributed equally to this article. 
ports suggest that the inactivation of nitric oxide caused by up-regulation of reactive oxygen species generation may contribute importantly to lead-induced hypertension [4-6]. Additionally, increased nicotinamide adenine dinucleotide phosphate oxidase activity [7] and down-regulated expression of catalase [8] have also been shown to contribute to $\mathrm{Pb}$-induced hypertension. $\mathrm{Pb}$ poisoning affects the hematopoietic system, inducing anemia by the unusual mechanism of rapid red blood cell destruction, as well as by inhibiting hemoglobin synthesis $[9,10]$.

Korean red ginseng (KRG) has gained attention in the Orient and the West as a tonic agent, health food, and/ or alternative herbal therapeutic agent. Positive pharmacological effects of KRG have been reported in the treatment of high blood pressure, atherosclerosis, and hyperlipidemia [11]. KRG has been shown to reduce oxidative damage incurred in various diseases [12]. This effect has been shown to be due to its ability to inhibit the generation of reactive oxigen species in blood vessels by reducing the activity of NADPH oxidase [13]. Furthermore, KRG can increase nitric oxide production in vascular endothelial cells [14-16], and affects vasodilation to reduce blood pressure [17]. Effects of KRG on blood pressure reduction have been shown in both humans and animals [14,15]. Administration of KRG has also been shown to reduce arterial stiffness in healthy human individuals [18].

Overall, reports suggest that KRG may be protective against hypertension, the generation of reactive oxygen species, and decreased hemopoiesis caused by exposure to $\mathrm{Pb}$, but this hpothesis has not yet been confirmed. The present study aimed to examine whether KRG can have such an effect on $\mathrm{Pb}$-induced physiological changes.

\section{MATERIALS AND METHODS}

\section{Animals and Korean red ginseng treatment}

Sprague-Dawley (SD) rats (average weight, $200 \mathrm{~g}$ ) were obtained from Samtako (Osan, Korea). Extract (Hongsamjung) of KRG was provided by the Korea Ginseng Corporation (Daejeon, Korea). KRG extract $(100 \mathrm{mg} / \mathrm{kg} /$ day) was administered to SD rats for 12 weeks. $\mathrm{Pb}$ acetate was purchased from Sigma-Aldrich (St Louis, MO, USA).

\section{Lead exposure}

Experimental animals were divided into four groups: untreated, $\mathrm{Pb}$ alone, $\mathrm{Pb}$ plus $\mathrm{KRG}$, and $\mathrm{KRG}$ alone. Each group was housed $(30 \times 20 \mathrm{~cm})$ under a $12 / 12-\mathrm{h}$ light/dark cycle at constant temperature $\left(20\right.$ to $\left.25^{\circ} \mathrm{C}\right)$ and humidity (50 to $60 \%)$. $\mathrm{Pb}$ exposure was achieved for 12 weeks by giving $100 \mathrm{ppm} \mathrm{Pb}$ (as $0.48 \mathrm{mM}$ lead acetate) in sterilized drinking water. All animal procedures were in accordance with the Chungnam National University Guide for the Care and Use of Laboratory Animals.

\section{Determination of lead concentration and blood cell counting}

At 12 weeks after $\mathrm{Pb}$ exposure, rat blood $(4 \mathrm{~mL})$ was collected in tubes containing heparin. The blood $\mathrm{Pb}$ concentration was determined at the Seoul Medical Science Institute (SCL, Korea) by atomic absorption spectrometry. The number of white blood cells, red blood cells, and platelets in $3 \mathrm{~mL}$ of whole blood was counted at SCL.

\section{Determination of glutathione concentration}

Plasma levels of glutathione were measured using the QuantiChrom Glutathione Assay Kit DIGT-250 (Gentaur, Brussels, Belgium). Briefly, an arterial blood sample was collected in an EDTA-coated tube and centrifuged (2000 g, $5 \mathrm{~min}$ ) to obtain plasma. Plasma $(50 \mu \mathrm{L})$ was diluted 10 -fold in PBS. Diluted plasma $(240 \mu \mathrm{L})$ was mixed with an equal volume of assay reagent $\mathrm{A}$, and centrifuged $(14,000 \mathrm{rpm}, 5 \mathrm{~min})$. The mixture of supernatant $(200 \mu \mathrm{L})$ with assay reagent $\mathrm{B}$ $(100 \mu \mathrm{L})$ was incubated at RT for 25 minutes, and the level of glutathione was determined by measuring absorbance at $412 \mathrm{~nm}$.

\section{Measurement of blood pressure}

Systolic blood pressure was measured in each rat's tail, initially and at 4,8 , and 12 weeks later, using a specially devised blood pressure monitoring system (ML125, AD Instruments, Colorado Springs, CO, USA). Body weights were measured using an electronic scale (MWII-6000N, CAS Co, Korea). During measurement, rats were fixed in an animal holder to prevent any moving, and pre-heated in a chamber at $35^{\circ} \mathrm{C}$ for 15 minutes to ensure psychological stability. A cuff with a pneumatic pulse sensor was then attached to the tail. Blood pressure values were averaged from at least three consecutive readings obtained from each rat.

\section{Statistical analyses}

Using SPSS ver. 17.0 (SPSS Inc., Chicago, IL, USA), a repeated measure ANOVA was carried out to detect differences in blood pressure among tested groups, and 
one-way ANOVA was employed to compare $\mathrm{Pb}$ concentration, and generation of reactive oxygen species and antioxidants. A $p$-value of $\leq 0.05$ was deemed to indicate statistical significance for all variables.

\section{RESULTS AND DISCUSSION}

\section{Effect of Korean red ginseng extract on lead- induced hypertension}

To determine whether KRG had a protective effect against $\mathrm{Pb}$-induced hypertension, $\mathrm{Pb}$ alone (100 ppm) or $\mathrm{Pb}$ plus KRG (100 mg/kg/day) was administered to rats for 12 weeks. After every 4 weeks of treatment, the blood pressure was measured using the tail-cuff protocol described in the Materials and Methods. An increase in blood pressure was observed at 8 weeks after exposure to $\mathrm{Pb}$ (100 ppm) (Fig. 1). After 12 weeks of treatment, the blood pressure of the Pb plus KRG group $(134.8 \pm 2.0 \mathrm{mmHg})$ was significantly lower than that of rats exposed to $\mathrm{Pb}$ alone (144.4 $\pm 1.5 \mathrm{mmHg}$ ) (Fig. 1). This suggests that KRG has a suppressive effect on $\mathrm{Pb}$ induced hypertension; however, no effect on heart rate or body weight was observed in the four test groups (Table 1).

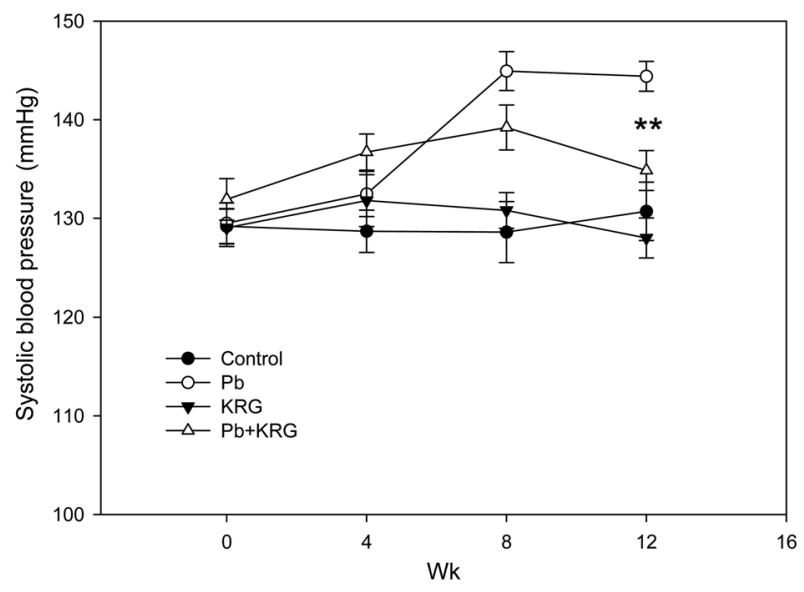

Fig. 1. Effect of Korean red ginseng (KRG) on systolic blood pressure in rats exposed to lead $(\mathrm{Pb})$ acetate $(100 \mathrm{ppm})$. KRG (100 mg/kg/day) was administered for 12 weeks. Each point represents the mean with standard error ( $n=14-15)$. Pb, Pb-treated group; KRG, KRG-treated group; Pb+KRG, $\mathrm{Pb}$ - and KRG-treated group. ${ }^{* *} p<0.01$.
It is well-known that chronic $\mathrm{Pb}$ exposure is associated with elevated blood pressure. In multivariate-adjustment models, a blood $\mathrm{Pb}$ concentration $\geq 5 \mu \mathrm{g} / \mathrm{dL}$ has been shown to be associated with higher systolic and diastolic blood pressure (BP) in blacks, but not whites [19]. Compared with their counterparts with a low blood $\mathrm{Pb}$ concentration, black men with a blood $\mathrm{Pb}$ concentration $\geq 5 \mu \mathrm{g} / \mathrm{dL}$ had systolic and diastolic BPs that were 1.67 and $1.68 \mathrm{mmHg}$ higher, respectively; black women had systolic and diastolic BPs that were 2.48 and $2.22 \mathrm{mmHg}$ higher, respectively [19]. Furthermore, chronic lowdose $\mathrm{Pb}$ exposure has been shown to increase reactive oxygen species generation, decrease nitric oxide generation, and alter the endothelium-independent relaxation response [20]. The present study confirms that blood pressure can be increased by $\mathrm{Pb}$ exposure, and suggests the possibility that long-term administration of KRG $(100 \mathrm{mg} / \mathrm{kg}$ /day) may interfere with pathophysiological mechanism(s) of hypertension. Previously, Kim et al. [13] suggested that saponin compounds in KRG may down-regulate hypertension; however, this has yet to be clarified.

\section{Effect of KRG on lead-induced oxidative injury}

To determine the effect of chronic $\mathrm{Pb}$ exposure on antioxidant capacity in rat blood, levels of glutathione were measured. Glutathione, a tri-peptide antioxidant, is found in all living cells, and helps protect against disease and aging. It plays an important role in oxidoreduction in cells, and is involved in detoxification and immune enhancement. The concentration of glutathione in the plasma of untreated rats was $62.2 \pm 7.9 \mu \mathrm{M}$; rats treated with $\mathrm{Pb}$ had significantly lower levels $(47.1 \pm 9.0 \mu \mathrm{M})$ (Fig. 2). Interestingly, plasma glutathione levels in blood from rats treated with KRG alone or $\mathrm{Pb}$ plus KRG were comparable to those in untreated controls (Fig. 2). The results demonstrate that KRG administration alone does not change plasma glutathione, but it can antagonize the reduction of plasma glutathione caused by $\mathrm{Pb}$ exposure. Furthermore, we confirmed that $\mathrm{Pb}$ poisoning can cause oxidative injury by decreasing the plasma level of glutathione, and that

Table 1. Hemodynamic changes induced by Korean red ginseng (KRG) in the lead $(\mathrm{Pb})$ exposed and control rats

\begin{tabular}{lcccc}
\hline & Control $(n=10)$ & $\mathrm{Pb}(n=15)$ & $\mathrm{KRG}(n=10)$ & $\mathrm{KRG}+\mathrm{Pb}(n=14)$ \\
\hline Blood pressure (mmHg) & $130.7 \pm 3.0$ & $144.4 \pm 1.5^{*}$ & $128.0 \pm 2.0$ & $134.8 \pm 2.0^{*}$ \\
Heart rate (beat per min) & $355 \pm 12$ & $370 \pm 11$ & $349 \pm 13$ & $374 \pm 10$ \\
Body weight (g) & $490 \pm 9$ & $479 \pm 11$ & $481 \pm 9$ & $494 \pm 8$ \\
\hline
\end{tabular}

Values are presented as mean \pm SE.

$" p<0.05$ vs. control group, ${ }^{\#} p<0.05$ vs. $\mathrm{Pb}$ treated group. 


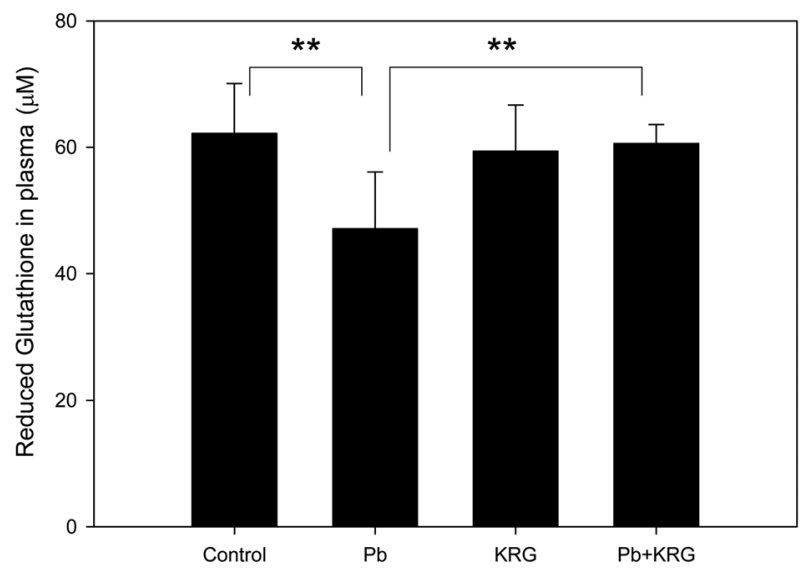

Fig. 2. Effect of Korean red ginseng (KRG) on glutathione concentrations in the plasma of rats exposed to lead (Pb) (100 ppm) and KRG extract $(100 \mathrm{mg} / \mathrm{kg} /$ day) for 12 weeks. Each bar represents the mean and standard error ( $n=6)$. Pb, Pb-treated group; KRG, KRG-treated group; Pb+KRG, $\mathrm{Pb}$ - and KRG-treated group. ${ }^{* *} p<0.01$.

KRG enhanced the production of the reduced form of glutathione, which prevents oxidative injury.

\section{Effect of KRG on plasma lead concentration}

To determine the effect of long-term administration of $\mathrm{KRG}$ on $\mathrm{Pb}$ accumulation, plasma $\mathrm{Pb}$ concentrations were determined using atomic absorption spectrometry. The concentration of $\mathrm{Pb}$ in plasma from rats treated with KRG for 12 weeks $(0.23 \pm 0.05 \mu \mathrm{g} /$ $\mathrm{dL}, \mathrm{n}=6)$ was comparable to that of untreated control rats $(0.32 \pm 0.04 \mu \mathrm{g} / \mathrm{dL}, \mathrm{n}=6)$ (Table 2). The plasma concentration of $\mathrm{Pb}$ in rats provided with drinking water containing $100 \mathrm{ppm} \mathrm{Pb}$ acetate for 12 weeks was $14.60 \pm 0.71 \mu \mathrm{g} / \mathrm{dL}$; this was about 50 -fold higher than that measured in untreated control rats. As the World Health Organization and the Centers for Disease Control and Prevention define childhood $\mathrm{Pb}$ poisoning as a whole-blood $\mathrm{Pb}$ concentration $\geq 10 \mu \mathrm{g} / \mathrm{dL}$ [20-23], our animal model of $\mathrm{Pb}$ poisoning covers an appropriate range of concentrations. Treatment with KRG (100 mg/ $\mathrm{kg} /$ day) for 12 weeks was unable to reduce the elevated blood $\mathrm{Pb}$ concentration (Table 2).
Table 2. Changes of Plasma lead $(\mathrm{Pb})$ concentration induced by Korean red ginseng (KRG) in the lead exposed and control rats

\begin{tabular}{lcc}
\hline Plasma $\mathrm{Pb}(\mu \mathrm{g} / \mathrm{dL})$ & Control $(n=6)$ & $\mathrm{Pb}(100 \mathrm{ppm})(n=7)$ \\
\hline Basal (vehicle) & $0.32 \pm 0.04$ & $14.60 \pm 0.71^{*}$ \\
KRG $(100 \mathrm{mg} / \mathrm{kg})$ & $0.23 \pm 0.05$ & $14.72 \pm 0.77$ \\
\hline
\end{tabular}

Values are presented as mean \pm SE.

" $p<0.05$ vs. control group.

\section{Effect of KRG on hematological alterations in- duced by long-term lead exposure}

To investigate the effect of KRG on hematological alterations induced by long-term $\mathrm{Pb}$ exposure, the number of red blood cells, white blood cells, and platelets in the blood was determined in rats provided with drinking water containing $100 \mathrm{ppm} \mathrm{Pb}$ acetate for 12 weeks. The number of red blood cells in long-term $\mathrm{Pb}$-exposed rats $\left(7.11 \pm 0.24 \times 10^{6} / \mathrm{mm}^{3}\right)$ was significantly lower than that of untreated controls $\left(7.71 \pm 0.12 \times 10^{6} / \mathrm{mm}^{3}\right)$ and KRG-treated rats $\left(7.58 \pm 0.13 \times 10^{6} / \mathrm{mm}^{3}\right)$ (Table 3). The number of red blood cells in Pb plus KRG-treated rats was also higher than that of rats exposed to $\mathrm{Pb}$ alone, but this difference was not statistically significant (Table 3 ).

The number of white blood cells and platelets in $\mathrm{Pb}$ exposed rats was significantly increased, compared with controls, but no such difference was found when comparing controls with KRG-treated rats (Table 3). Long-term KRG treatment increased the number of white blood cells $\left(6.49 \pm 1.88 \times 10^{3} / \mathrm{mm}^{3}\right)$, but this increase was not significantly different from controls (Table 3 ). Pb plus KRG treatment reduced the increase in white blood cell number $\left(5.33 \pm 0.47 \times 10^{3} / \mathrm{mm}^{3}\right)$ compared with $\mathrm{Pb}$ alone, but this also was not statistically significant (Table 3 ).

$\mathrm{Pb}$ poisoning causes anemia by affecting the hematopoietic system. The present study confirmed unusual decreases in red blood cells in $\mathrm{Pb}$-treated rats, which did not recover with $\mathrm{KRG}$ treatment. $\mathrm{Pb}$ seriously disrupts the function of delta-aminolevulinic acid dehydratase, which plays a role in heme synthesis $[9,10]$. Because KRG compounds enhance hematopoiesis [24], longterm KRG treatment may alleviate anemia by reversing $\mathrm{Pb}$-induced heme synthesis disruption.

Table 3. Hematological findings induced by Korean red ginseng (KRG) in the lead $(\mathrm{Pb})$ exposed and control rats

\begin{tabular}{lcccc} 
& Control $(n=10)$ & $\mathrm{Pb}(n=7)$ & $\mathrm{KRG}(n=10)$ & $\mathrm{KRG}+\mathrm{Pb}(n=6)$ \\
\hline $\mathrm{RBC}\left(\times 10^{6} / \mathrm{mm}^{3}\right)$ & $7.71 \pm 0.12$ & $7.22 \pm 0.1^{*}$ & $7.58 \pm 0.13$ & $7.66 \pm 0.25$ \\
$\mathrm{WBC}\left(\times 10^{3} / \mathrm{mm}^{3}\right)$ & $5.42 \pm 0.62$ & $6.49 \pm 1.88$ & $5.15 \pm 0.49$ & $5.33 \pm 0.47$ \\
Platelet $\left(\times 10^{3} / \mathrm{mm}^{3}\right)$ & $843 \pm 16$ & $1141 \pm 205$ & $875 \pm 26$ & $1026 \pm 61$ \\
\hline
\end{tabular}

Values are presented as mean \pm SE.

RBC, red blood cell; WBC, white blood cell.

$p<0.05$ vs. control group. 


\section{Summary}

Although KRG did not affect heart rate, body weight, or white blood cell numbers, treatment with KRG significantly lowered blood pressure, raised plasma glutathione, and increased the number of red blood cells. Despite these changes, the elevated blood $\mathrm{Pb}$ concentration was not reduced by treatment with KRG (100 mg/ $\mathrm{kg}$ ), suggesting that KRG does not prevent $\mathrm{Pb}$ uptake. These data indicate that treatment with $\mathrm{KRG}$ in $\mathrm{Pb}$ exposed groups reduced oxidative stress and lowered blood pressure. This suggests that KRG might protect against $\mathrm{Pb}$-induced hypertension and oxidative stress.

\section{ACKNOWLEDGEMENTS}

We heartily thank for financial support from the Korean Society of Ginseng in 2009 funded by Korea Ginseng Corporation and this work was partly supported by Basic Science Research Program through the National Research Foundation of Korea (R13-2007-020-00000-0). The English in this document has been checked by at least two professional editors, both native speakers of English.

\section{REFERENCES}

1. Harlan WR. The relationship of blood lead levels to blood pressure in the U.S. population. Environ Health Perspect 1988;78:9-13.

2. Sharp DS, Becker CE, Smith AH. Chronic low-level lead exposure. Its role in the pathogenesis of hypertension. Med Toxicol 1987;2:210-232.

3. Sharp DS, Osterloh J, Becker CE, Bernard B, Smith AH, Fisher JM, Syme SL, Holman BL, Johnston T. Blood pressure and blood lead concentration in bus drivers. Environ Health Perspect 1988;78:131-137.

4. Vaziri ND, Liang K, Ding Y. Increased nitric oxide inactivation by reactive oxygen species in lead-induced hypertension. Kidney Int 1999;56:1492-1498.

5. Gonick HC, Ding Y, Bondy SC, Ni Z, Vaziri ND. Leadinduced hypertension: interplay of nitric oxide and reactive oxygen species. Hypertension 1997;30:1487-1492.

6. Vaziri ND, Ding Y, Ni Z, Gonick HC. Altered nitric oxide metabolism and increased oxygen free radical activity in lead-induced hypertension: effect of lazaroid therapy. Kidney Int 1997;52:1042-1046.

7. Vaziri ND, Lin CY, Farmand F, Sindhu RK. Superoxide dismutase, catalase, glutathione peroxidase and NADPH oxidase in lead-induced hypertension. Kidney Int 2003;63:186-194.
8. Lee KH, Lee SK, Kim HS, Cho EJ, Joo HK, Lee EJ, Lee JY, Park MS, Chang SJ, Cho CH, et al. Overexpression of Ref-1 inhibits lead-induced endothelial cell death via the upregulation of catalase. Korean J Physiol Pharmacol 2009;13:431-436.

9. Patrick L. Lead toxicity part II: the role of free radical damage and the use of antioxidants in the pathology and treatment of lead toxicity. Altern Med Rev 2006;11:114127.

10. Patrick L. Lead toxicity, a review of the literature. Part 1: Exposure, evaluation, and treatment. Altern Med Rev 2006;11:2-22.

11. Nam KY. Clinical applications and efficacy of Korean ginseng. J Ginseng Res 2002;26:111-131.

12. Kim EH, Rhee DK. Anti-oxidative properties of ginseng. J Ginseng Res 2009;33:1-7.

13. Kim CS, Park JB, Kim KJ, Chang SJ, Ryoo SW, Jeon BH. Effect of Korean red ginseng on cerebral blood flow and superoxide production. Acta Pharmacol Sin 2002;23:1152-1156.

14. Jeon BH, Kim CS, Park KS, Lee JW, Park JB, Kim KJ, Kim SH, Chang SJ, Nam KY. Effect of Korean red ginseng on the blood pressure in conscious hypertensive rats. Gen Pharmacol 2000;35:135-141.

15. Jeon BH, Kim CS, Kim HS, Park JB, Nam KY, Chang SJ. Effect of Korean red ginseng on blood pressure and nitric oxide production. Acta Pharmacol Sin 2000;21:10951100.

16. Han K, Shin IC, Choi KJ, Yun YP, Hong JT, Oh KW. Korean red ginseng water extract increases nitric oxide concentrations in exhaled breath. Nitric Oxide 2005;12:159162.

17. Chang SJ, Suh JS, Jeon BH, Nam KY, Park HK. Vasorelaxing effect by protopanaxatriol and protopanaxadiol of Panax ginseng in the pig coronary artery. J Ginseng Res 1994;18:95-101.

18. Jovanovski E, Jenkins A, Dias AG, Peeva V, Sievenpiper J, Arnason JT, Rahelic D, Josse RG, Vuksan V. Effects of Korean red ginseng (Panax ginseng C.A. Mayer) and its isolated ginsenosides and polysaccharides on arterial stiffness in healthy individuals. Am J Hypertens 2010;23:469-472.

19. Vupputuri S, He J, Muntner P, Bazzano LA, Whelton PK, Batuman V. Blood lead level is associated with elevated blood pressure in blacks. Hypertension 2003;41:463-468.

20. Courtois E, Marques M, Barrientos A, Casado S, LopezFarre A. Lead-induced downregulation of soluble guanylate cyclase in isolated rat aortic segments mediated by reactive oxygen species and cyclooxygenase-2. J Am Soc Nephrol 2003;14:1464-1470. 
21. Centers for Disease Control and Prevention (CDC). Blood lead levels-United States, 1999-2002. MMWR Morb Mortal Wkly Rep 2005;54:513-516.

22. Kosnett MJ, Wedeen RP, Rothenberg SJ, Hipkins KL, Materna BL, Schwartz BS, Hu H, Woolf A. Recommendations for medical management of adult lead exposure.
Environ Health Perspect 2007;115:463-471.

23. Gracia RC, Snodgrass WR. Lead toxicity and chelation therapy. Am J Health Syst Pharm 2007;64:45-53.

24. Lee JW, Do JH. Current studies on browning reaction products and acidic polysaccharide in Korean red ginseng. J Ginseng Res 2006;30:41-48. 